\title{
Characteristics of speech rate and pause in children with spastic cerebral palsy and their relationships with speech intelligibility
}

\author{
Pil Yeon Jeong ${ }^{1} \cdot$ Hyun Sub Sim ${ }^{2, *}$ \\ ${ }^{1}$ Ewha Womans University Center for Child Development and Disability, Seoul, Korea \\ ${ }^{2}$ Department of Communication Disorders, Ewha Womans University, Seoul, Korea
}

\begin{abstract}
The current study aimed to identify the characteristics of speech rate and pause in children with spastic cerebral palsy $(\mathrm{CP})$ and their relationships with speech intelligibility. In all, 26 children with CP, 4 with no speech motor involvement and age-appropriate language ability (NSMI-LCT), 6 with no speech motor involvement and impaired language ability (NSMI-LCI), 6 with speech motor involvement and age-appropriate language ability (SMI- LCT), and 10 with speech motor involvement and impaired language ability (SMI-LCI) participated in the study. Speech samples for the speech rate and pause analysis were extracted using a sentence repetition task. Acoustic analysis were made in Praat. First, it was found that regardless of the presence of language impairment, significant group differences between the NSMI and SMI groups were found in speech rate and articulation rate. Second, the SMI groups showed a higher ratio of pause time to sentence production time, more frequent pauses, and longer durations of pauses than the NSMI groups. Lastly, there were significant correlations among speech rate, articulation rate, and intelligibility. These findings suggest that slow speech rate is the main feature in SMI groups, and that both speech rate and articulation rate play important roles in the intelligibility of children with spastic CP.
\end{abstract}

Keywords: spastic cerebral palsy, rate, pause, intelligibility

\section{1. 서론}

말속도는 뇌성마비 아동의 마비말장애를 임상적으로 판단하 는 데 있어서 일반아동과 구분 짓는 주요 예측변수이다(Allison \& Hustad, 2018; Redfold, 2014). 적절한 말속도는 말명료도 증진 을 위한 일차적 목표이고(Pennington et al., 2010), 조음속도와 쉼 패턴은 성공적인 중재를 이끄는 데 중요한 역할을 한다(Darling-
White et al., 2018).

말속도는 발화 구간과 쉼 빈도 및 쉼 구간으로 이루어져 나타 나게 되는데(Hammen \& Yorkston, 1996), 이 요소들의 실현 양상 이 말명료도에 까지 영향을 미친다. 조음속도가 안정적인 상태 에서 쉼의 빈도가 증가한다면 쉼 시간이 길어지기 때문에 말속 도는 감소하게 된다(Goldman-Eisler, 1968). 만약 쉼이 적절하게 나타난다면 부정확한 말소리를 해석하고, 이해하는데 필요한

*simhs@ewha.ac.kr, Corresponding author

Received 31 July 2020; Revised 12 September 2020; Accepted 13 September 2020

(c) Copyright 2020 Korean Society of Speech Sciences. This is an Open-Access article distributed under the terms of the Creative Commons Attribution NonCommercial License (http://creativecommons.org/licenses/by-nc/4.0) which permits unrestricted non-commercial use, distribution, and reproduction in any medium, provided the original work is properly cited. 
더 많은 시간을 가질 수 있어서 말명료도가 증가할 수도 있지만 부적절한 구문위치에서 나타난다면 말명료도는 오히려 감소할 수도 있다(Hammen \& Yorkston, 1996).

일반적으로 뇌성마비 아동의 말속도는 느리다고 알려져 있 다(Hustad et al., 2010). 3세(Hodge \& Gotzke, 2014), 4-12세(Kim \& Lee, 2018), 4-16세(Jeong, 2019) 아동을 대상으로 한 연구에서 공통적으로 느린 말속도를 보고하고 있으며 말속도 뿐만 아니 라 단어수준에서의 조음속도 또한 일반아동에 비해 더 느린 특 성을 보인다(Allison \& Hustad, 2018; Jeong et al., 2016). 일반아 동의 경우에 연령이 증가함으로써 말속도가 증가하고, 12-13세 경에 이르러 성인과 유사한 말속도를 보이게 된다(Nip \& Green, 2013). 연령이 올라갈수록 말속도가 증가하는 것은 전체 말속도 와 조음속도는 증가하고, 쉼 시간은 감소된 결과라고 할 수 있 다(Nip \& Green, 2013). 이는 연령이 증가함에 따라 말운동통제 능력과 인지-언어적 능력의 효율성이 향상된 것과 연관이 있다 (Darling-White et al., 2018; Nip \& Green, 2013). 그러나 뇌성마비 아동의 경우에는 연령이 증가한다 하여도 말속도는 증가하지 않는데(Darling-White et al., 2018), 근육 및 운동능력이 저하되 어 있고, 호흡이 짧아서 조음속도 자체가 느리고, 단어 간 또는 단어 내에서 쉼의 구간이 길어지기 때문이다.

지금까지 뇌성마비 아동을 대상으로 말속도 관련 요소들에 관한 연구들을 살펴보면 일반아동과 말속도 수행 차이를 비교 해 보거나(Kim \& Lee, 2018), 뇌성마비 유형 간에 차이를 살펴 본 연구(Nam \& Kwon, 2005; Nam \& Kwon, 2009)가 진행되어 왔 다. 조음속도를 단어수준에서만 살펴보거나(Jeong et al., 2016), 쉼(pause)의 세부요소들을 뇌성마비 유형별로 분석한 연구(Nam \& Kwon, 2005; Nam \& Kwon, 2009)도 실시되어져 왔으나 후속 연구는 매우 제한적인 실정이다. 말속도 뿐만 아니라 쉼의 세부 적인 특성을 알아볼 필요가 있는 이유로 뇌성마비 아동의 호흡 문제(Kim \& Lee, 2018; Jeong, 2019)와 연관 지어 볼 수 있다. 발 화 과정에서 충분한 호흡적 지지가 이루어지지 않는다면 쉼의 빈도가 증가하거나 쉼의 시간이 길어지는 양상으로 나타나기 때문이다. 특히 경직형 뇌성마비의 호흡문제는 호기 근육의 약 화와 폐활량 감소 양상이 두드러지면서 발화과정에 부정적인 영향을 미치게 된다.

또한 말명료도가 마비말장애 중재에서 주요한 목표임에도 불구하고, 성인 뇌성마비 화자를 대상으로 이루어진 연구는 있 었으나(Han et al., 2013; Lee et al., 2007), 뇌성마비 아동을 대상 으로 한 연구는 매우 미비하게 이루어져 왔다. 따라서 뇌성마비 아동을 대상으로 하여 말속도와 쉼의 세부요인들의 특성을 살펴 보고, 말명료도와의 관련성에 대해서도 알아볼 필요가 있겠다.

아울러 뇌성마비 아동은 동질적인 그룹이라기보다는 말, 언 어문제의 세부적인 양상에서 차이가 나는 이질적인 집단이기 때문에(Hustad et al., 2010) 말, 언어장애 유무에 따른 그룹 간 차 이를 알아볼 필요가 있다. 최근에 종단연구를 통해 4세, 5 세, 6 세 뇌성마비 아동을 대상으로 하여 말장애 유무에 따라 말장애 가 없는 그룹(No Speech Motor Involvement, 이하 NSMI)과 말장 애가 있는 그룹(Speech Motor Involvement, 이하 SMI)으로 구분
하여 말속도, 조음속도 및 쉼의 차이를 연령과 문장길이에 따라 살펴본 결과, NSMI와 SMI 그룹 모두 연령의 증가에 따른 차이 는 없었으나 문장길이에 따른 차이는 있다는 보고가 있었고, $\mathrm{NSMI}$ 그룹은 긴 문장에서 조음속도와 말속도가 증가하였지만 $\mathrm{SMI}$ 그룹은 문장길이가 길어지거나 연령이 올라가도 말속도가 증가하지 않았다는 결과를 제시하였다(Darling-White et al., 2018).

그러나, 선행연구(Darling-White et al., 2018)에서는 말장애 유 무에 따른 그룹 간 차이만을 제시하였으며, 후속연구를 통해 언 어문제의 동반여부에 따라 말속도와 쉼의 차이를 알아볼 필요 가 있다고 제시하였다. 따라서 본 연구에서는 경직형 뇌성마비 아동의 하위그룹을 말장애와 언어장애 동반 유무에 따라 언어 문제가 없는 그룹(age appropriate language, cognition abilities, 이 하 LCT)과 언어문제가 있는 그룹(impaired language, cognition abilities, 이하 LCI)으로 세부적으로 분류하여 말과 언어문제가 없는 NSMI-LCT 그룹, 말문제는 없지만 언어문제가 있는 NSMI-LCI 그룹, 말문제는 있지만 언어문제는 없는 SMI-LCT 그 룹, 말과 언어문제가 함께 동반된 SMI-LCI 그룹으로 분류하여 말속도와 쉼의 특성을 살펴보고, 말명료도와의 관계에 대해서 도 확인해 보고자 하였다.

구체적인 연구문제는 다음과 같다.

첫째, 경직형 뇌성마비 아동의 하위그룹별 말속도(말속도, 조 음속도)는 차이가 있는가?

둘째, 경직형 뇌성마비 아동의 하위그룹별 쉄(쉼 시간의 비 율, 평균 쉄 횟수, 평균 쉼 시간)은 차이가 있는가?

셋째, 경직형 뇌성마비 아동의 말속도와 쉼 및 말명료도와의 관계는 어떠한가?

\section{2. 연구방법}

\section{1. 연구대상}

본 연구에는 선행연구(Darling-White et al., 2018)와 같이 뇌성 마비로 의학적 진단을 받고, 청력에 문제가 없는 생활연령 평균 7.7세(범위 4-13세)의 경직형 뇌성마비 아동 26명이 참여하였다. 본 연구의 참여대상은 특수학교 및 재활병원에서 모두 재활치료 를 받고 있는 아동이었다. 뇌성마비 하위그룹 간 연령의 차이는 없 었으나 $[F(3,22)=.060, p>.05]$, 자음정확도 $[F(3,22)=10.432, p<.001]$ 와 수용어휘능력 점수 $[F(3,22)=9.403, p<.001]$ 에서는 그룹 간에 유의한 차이를 나타내었다. GMFCS 분류체계는 의료 차트 검토 를 통해 작성하였다. 표 1 에 연구대상의 특성을 제시하였다. 
표 1. 경직형 뇌성마비 아동의 하위그룹별 특성

Table 1. Demographic characteristics of children with spastic cerebral palsy by subgroups

\begin{tabular}{c|c|c|c|c}
\hline & $\begin{array}{c}\text { NSMI-LCT } \\
(\mathrm{n}=4)\end{array}$ & $\begin{array}{c}\text { NSMI-LCI } \\
(\mathrm{n}=6)\end{array}$ & $\begin{array}{c}\text { SMI-LCT } \\
(\mathrm{n}=6)\end{array}$ & $\begin{array}{c}\text { SMI-LCI } \\
(\mathrm{n}=10)\end{array}$ \\
\hline 평균연령(세) & $7.93(3.91)$ & $7.71(1.24)$ & $7.01(4.73)$ & $8.16(3.83)$ \\
\hline 생활연령 범위 & $5-13$ & $8-11$ & $4-13$ & $5-13$ \\
\hline 남: 여 & $4: 0$ & $6: 0$ & $5: 1$ & $8: 2$ \\
\hline 자음정확도(\%) & $100(0)$ & $99.76(1.58)$ & $50.39(39.48)$ & $49.84(32.51)$ \\
\hline 수용어휘 & 119.9 & 77.62 & 125.27 & 45.14 \\
능력(점) & $(50.57)$ & $(15.43)$ & $(65.32)$ & $(29.62)$ \\
\hline GMFCS & & & & \\
I & 1 & 0 & 0 & 0 \\
II & 1 & 2 & 1 & 0 \\
III & 1 & 4 & 0 & 2 \\
IV & 1 & 0 & 1 & 0 \\
V & 0 & 0 & 4 & 8 \\
\hline
\end{tabular}

Values are presented as mean (SD).

NSMI, no speech motor involvement; SMI, speech motor involvement; LCT, age appropriate language, cognition abilities; LCI, impaired language, cognition abilities; GMFCS, Gross Motor Function Classification System.

2.2. 연구방법

\subsection{1. 실험과제}

말속도 측정을 위해 선행연구(Darling-White et al., 2018; Hustad et al., 2010)와 같이 모든 참여아동에게 제시되는 과제의 동질성 을 유지하기 위해 컴퓨터에서 재생되는 성인화자의 목표문장을 듣고서 그 문장을 따라말하게 하였다. 목표문장은 선행연구(Han et al., 2013)에서 사용한 운반구('OO가 저기 있다')에 아동 연령 을 고려하여 마찰음과 파찰음이 포함되지 않은 단어(예: 바다, 파도, 두부, 기타, 구두, 베게)를 넣어서 제작하였다. 발화샘플의 수집은 디지털 녹음기(ICD-UX512F, SONY)를 사용하였고, 바 른 자세로 앉은 상태에서 입과 녹음기 간 $10 \mathrm{~cm}$ 정도의 거리를 유지하면서 녹음하였다.

하위그룹 간 분류를 위해 실시한 언어능력 평가는 선행연구 (Jeong, 2019)와 같이 Kim et al.(2010)의 수용 및 표현어휘력 검 사(Receptive \& Expressive Vocabulary Test, REVT) 가운데 수용 어휘력 검사를 사용하였다. 자음정확도 평가는 Kim et al.(2007) 의 아동용 발음평가(Assessment of Phonology \& Articulation for Children, APAC)를 사용하였다.

\subsection{2. 측정방법}

측정도구는 선행연구(Darling-White et al., 2018)와 동일하게 Praat을 사용하여 분석하였다. 측정방법으로 문장구간(sentence duration)은 문장의 시작과 끝 시간으로 정의하였다. 문장의 시 작은 Praat의 스펙트로그래프 상에 첫 음절의 산출과 함께 시각 적, 청각적 신호가 나타날 때로 하였고, 문장의 끝은 마지막 음 산출 후 음향학적 에너지가 사라질 때를 기준으로 하였다. 쉼은 0.15초 이상의 묵음구간이 있을 때로 정의하였다(Stathopoulos et al., 2014). 쉼의 길이는 말소리 분절(speech segment)의 종료시 점(offset)부터 다음 말소리 분절 음향에너지의 시작지점(onset)
까지를 기준으로 하였다.

\subsection{3. 측정변수}

측정변수는 선행연구(Darling-White et al., 2018)와 같이 말속 도, 조음속도, 쉼 시간의 비율, 평균 쉼 횟수, 평균 쉼 시간으로 하였다. 말속도는 전체 문장구간 동안 산출한 음절수(음절수/전 체 문장구간)이고, 조음속도는 쉼 시간을 제외하고, 전체 문장 구간 동안 산출한 음절수(음절수/전체 문장구간-쉼시간)로 정 의하였다. 쉼 시간의 비율은 전체 문장구간에서 총 쉼 시간을 나눈 값(총 쉼 시간/전체 문장구간)으로 1 에 가까울수록 문장에 서 쉼이 많다는 것이고, 0 에 가까우면 쉼이 적은 것을 반영한다 (Darling-White et al., 2018). 평균 쉼 횟수는 전체 문장수에서 총 쉄의 횟수(총 쉼의 횟수/전체 문장수)를 나눈 값이다. 평균 쉼 시 간은 총 쉼의 횟수에서 쉼 시간의 합을 나눈 값(쉼 시간의 합/총 쉼의 횟수)이다. 말명료도는 문장과제를 듣고 명료하게 알아들 은 정도를 7점 척도로 측정하였다. 말명료도 평가를 위해 대졸 학력 이상의, 뇌성마비 아동의 발화를 들은 적이 없는 생활연령 평균 32.5 세의 성인 13 명이 참여하였다.

\subsection{4. 통계분석}

집단 간 말속도와 쉼의 차이를 알아보기 위해 모든 변수에서 Levene의 등분산 가정이 충족되는 것을 확인한 후 일원분산분석 (one-way ANOVA)을 실시하였고, 하위그룹 간 차이가 있을 경우 사후분석은 Scheffe 검정을 사용하였으며 Bonferroni correction을 적용하여 유의수준을 0.012 로 조정하여 결과를 분석하였다. 말 속도 및 쉼과 말명료도와의 관계는 Pearson의 상관으로 분석하 였다. 본 연구의 자료는 IBM SPSS Statistics version 23 (IBM, Armonk, NY, USA)으로 분석하였다.

\section{3. 연구결과}

3.1. 경직형 뇌성마비 하위그룹 간 말속도, 조음속도의 차이 경직형 뇌성마비 하위그룹 간에 말속도는 유의한 차이를 보 였다 $[F(3,22)=17.405, p<.001]$. 어느 하위그룹에서 유의한 차이 가 있는지 사후분석을 실시한 결과, NSMI-LCT와 NSMI-LCI는 SMI-LCT, SMI-LCI와 각각 차이를 보였다.

경직형 뇌성마비 하위그룹 간 조음속도에서도 유의한 차이를 나타내었다 $F(3,22)=11.374, p<.001]$. 사후분석 결과, NSMI-LCT 와 NSMI-LCI는 SMI-LCT, SMI-LCI와 각각 차이를 나타내었다. 표 2 에는 말속도와 조음속도의 결과를, 표 3 과 표 4에는 사후분 석 결과를 제시하였다. 
표 2. 경직형 뇌성마비 아동의 하위그룹별 말속도의 차이 Table 2. Results of rate in children with spastic cerebral palsy by subgroups

\begin{tabular}{c|c|c|c|c}
\hline & $\begin{array}{c}\text { NSMI-LCT } \\
(\mathrm{n}=4)\end{array}$ & $\begin{array}{c}\text { NSMI-LCI } \\
(\mathrm{n}=6)\end{array}$ & $\begin{array}{c}\text { SMI-LCT } \\
(\mathrm{n}=6)\end{array}$ & $\begin{array}{c}\text { SMI-LCI } \\
(\mathrm{n}=10)\end{array}$ \\
\hline 말속도(SPS) & $3.46(.67)$ & $3.30(1.86)$ & $1.33(.70)$ & $1.45(.70)$ \\
\hline 조음속도(SPS) & $3.75(.45)$ & $3.83(.49)$ & $1.87(1.02)$ & $2.17(.75)$ \\
\hline
\end{tabular}

Values are presented as mean (SD).

NSMI, no speech motor involvement; SMI, speech motor involvement; LCT, age appropriate language, cognition abilities; LCI, impaired language, cognition abilities.; SPS, syllables per second

\section{표 3. 경직형 뇌성마비 아동의 하위그룹별 말속도에 대한 사후분석결과}

Table 3. Post hoc results of speech rate in children with spastic cerebral palsy by subgroups

\begin{tabular}{|c|c|c|c|c|}
\hline & 하위그룹 & 평균차 & 표준오차 & $p$-value \\
\hline \multirow{3}{*}{ NSMI-LCT } & vs. NSMI-LCI & .15 & .43 & .989 \\
\hline & vs. SMI-LCT & 2.12 & .43 & $.001^{*}$ \\
\hline & vs. SMI-LCI & 2.00 & .39 & $.001^{*}$ \\
\hline \multirow{2}{*}{ NSMI-LCI } & vs. SMI-LCT & 1.97 & .38 & $.001^{*}$ \\
\hline & vs. SMI-LCI & 1.85 & .34 & $.000^{*}$ \\
\hline SMI-LCT & vs. SMI-LCI & -.12 & .34 & .989 \\
\hline
\end{tabular}

${ }^{*} p<.012$.

NSMI, no speech motor involvement; SMI, speech motor involvement; LCT, age appropriate language, cognition abilities; LCI, impaired language, cognition abilities.

\section{표 4. 경직형 뇌성마비 아동의 하위그룹별 조음속도에 대한 사후분석결과}

Table 4. Post hoc results of articulation rate in children with spastic cerebral palsy by subgroups

\begin{tabular}{|c|c|c|c|c|}
\hline & 하위그룹 & 평균차 & 표준오차 & $p$-value \\
\hline \multirow{3}{*}{ NSMI-LCT } & vs. NSMI-LCI & -.08 & .48 & .999 \\
\hline & vs. SMI-LCT & 1.87 & .48 & $.008^{*}$ \\
\hline & vs. SMI-LCI & 1.77 & .48 & $.010^{*}$ \\
\hline \multirow{2}{*}{ NSMI-LCI } & vs. SMI-LCT & 1.95 & .42 & $.002^{*}$ \\
\hline & vs. SMI-LCI & 1.65 & .38 & $.003^{*}$ \\
\hline SMI-LCT & vs. SMI-LCI & -.30 & .38 & .891 \\
\hline
\end{tabular}

NSMI, no speech motor involvement; SMI, speech motor

involvement; LCT, age appropriate language, cognition abilities; LCI, impaired language, cognition abilities.

3.2. 경직형 뇌성마비 하위그룹 간 쉼 시간의 비율, 평균 쉼 횟수, 평균 쉼 시간의 차이

표 5 와 같이 경직형 뇌성마비 하위그룹별 쉼 시간의 비율 $[F(3,22)=1.319, p>.05]$, 평균 쉼 횟수 $[F(3,22)=1.483, p>.05]$ 및 평균 쉄 시간 $[F(3,22)=.235, p>.05]$ 은 유의한 차이가 나타나지 않았다.
표 5. 경직형 뇌성마비 하위그룹별 쉼의 차이

Table 5. Results of pause in children with spastic cerebral palsy by subgroups

\begin{tabular}{c|c|c|c|c}
\hline & $\begin{array}{c}\text { NSMI-LCT } \\
(\mathrm{n}=4)\end{array}$ & $\begin{array}{c}\text { NSMI-LCI } \\
(\mathrm{n}=6)\end{array}$ & $\begin{array}{c}\text { SMI-LCT } \\
(\mathrm{n}=6)\end{array}$ & $\begin{array}{c}\text { SMI-LCI } \\
(\mathrm{n}=10)\end{array}$ \\
\hline 쉼 시간의 비율(초) & $.09(.13)$ & $.13(.14)$ & $.26(.19)$ & $.30(.25)$ \\
\hline 평균 쉼 횟수(회) & $.75(.95)$ & $1.01(1.09)$ & $1.67(1.37)$ & $1.54(1.33)$ \\
\hline 평균 쉼 시간(초) & $.20(.33)$ & $.22(.15)$ & $.31(.26)$ & $.34(.32)$ \\
\hline
\end{tabular}

Values are presented as mean (SD)

NSMI, no speech motor involvement; SMI, speech motor

involvement; LCT, age appropriate language, cognition abilities; LCI, impaired language, cognition abilities.

3.3. 말속도, 쉼 및 말명료도와의 관계

말속도와 말명료도 $(r=.711, p<.001)$, 조음속도와 말명료도 $(r=.749, p<.001)$ 간에는 유의한 정적상관을 나타내었다. 그러나, 쉼 시간의 비율 $(r=.345, p>.05)$, 평균 쉼 횟수 $(r=.214, p>.05)$ 및 평균 쉼 시간 $(r=.321, p>.05)$ 과 말명료도에서는 유의미한 상관 이 나타나지 않았다.

\section{4. 논의 및 결론}

본 연구에서는 말, 언어문제의 유무에 따라 4 개의 하위그룹 으로 나누어 경직형 뇌성마비 아동의 말속도와 쉼의 특성에 대 하여 알아보고, 말명료도와의 관계에 대해서도 살펴보았다. 연 구결과에 따라 다음과 같이 논의를 하였다.

4.1. 경직형 뇌성마비 아동의 하위그룹 간 말속도와 조음속도의 차이

경직형 뇌성마비 아동의 하위그룹 간 말속도와 조음속도는 유 의한 차이를 보였다. NSMI-LCT와 NSMI-LCI 그룹은 SMI-LCT, SMI-LCI 그룹과 모두 차이를 나타내었다. 즉 언어문제 유무와 관계없이 말문제가 없는 NSMI 그룹에 비해 말문제가 있는 SMI 그룹에서는 유의하게 느린 말속도와 조음속도를 나타내었다.

이는 SMI 그룹의 말속도가 더 느리다는 선행연구와 일치하 는 결과이다(Hustad et al., 2010; Jeong, 2019). 일반아동과의 비 교연구에서도 뇌성마비 아동의 말산출 속도가 더 느리고(Kim \& Lee, 2018; Nip, 2013), 조음속도 또한 느리며 일반아동과 말산 출 특성에서 차이가 나는 요소라고 지적하고 있다(Allison \& Hustad, 2018). 또한 말소리장애 아동도 일반아동에 비해 말속도 가 더 느리다고 보고하고 있는데, 이러한 결과들을 볼 때 말문 제가 있는 경우에 조음산출의 속도가 느린 것은 일반아동과 구 분되는 말산출의 주요한 지표라 할 수 있겠다(Lee \& Kim, 2017).

말속도와 조음속도에서 SMI 그룹이 더 느리게 나타난 이유 로 경직형 뇌성마비 아동의 구강운동 속도와 협응력 저하가 관 련이 있다고 보여진다. Kim과 Lee(2018)는 일반아동과 뇌성마비 아동의 SMST-C(Speech Mechanism Screening Test for Children) 평가 결과, 뇌성마비 아동의 구강기능 구조와 기능이 일반아동 에 비해 현저히 낮은 수행능력을 보인다고 언급하면서 얼굴, 입 술 및 혀의 움직임뿐만 아니라 턱이나 치아의 교합도 비정상성 을 나타낸다고 설명하였다. 이는 본 연구에 참여한 경직형 뇌성 
마비 아동 가운데 GMFCS 수준이 V에 해당하는 아동이 상대적 으로 많았다는 점과도 연관지어 볼 수 있다. GMFCS V는 체간 과 머리의 조절에 제약이 있을 뿐만 아니라 이동성에 심각한 제 한이 있는 단계이다(Palisano et al., 1997). 따라서 하지뿐만 아니 라 상지의 운동성에도 제약이 있으므로 말산출 과정에서 영향 을 받게 될 것이고, 이러한 점이 말속도나 조음속도에 부정적 영향을 미쳤을 것으로 추측된다.

조음은 말산출 기관의 동작들을 통해 최종적으로 실현되기 때문에(Yoo \& Shin, 2020) 조음기관의 협응문제나 약화가 있다 면 결과적으로 말속도나 조음속도에서 제약이 나타날 수 있다. 즉 뇌성마비 아동이 조음 산출 동작을 할 때 구강을 개방하고 폐쇄하는 데 걸리는 시간이 더 많이 소요되면서 말속도가 느리 게 되는 것이다(Nip, 2013). Lee et al.(2014)도 SMI 그룹에서 F2 기울기가 더 좁게 나타나는데 이는 전반적 조음동작이 느린 것 을 반영하는 것이고, 특히 발화 동안 혀의 움직임이 제한적임을 나타내는 것이라고 제안하고 있다.

4.2. 경직형 뇌성마비 아동의 하위그룹 간 쉼 시간의 비율, 평균 쉼 횟수, 평균 쉼 시간의 차이

경직형 뇌성마비 아동의 하위그룹별 쉼 시간 비율, 평균 쉼 횟수 및 평균 쉼 시간은 통계적으로 유의한 차이가 나타나지 않 았다. 즉 4개의 하위그룹 간에 쉼의 특성들은 유사한 양상을 나 타낸다고 볼 수 있다. 그러나, 비록 통계적으로 유의하지는 않 았으나 평균값을 살펴보면 NSMI 그룹에 비해 SMI 그룹에서 평 균 쉼 시간의 비율은 더 높고, 평균 쉼 횟수는 더 많으며 평균 쉼 시간의 길이는 더 증가한 것을 보여준다.

이러한 결과는 말문제를 동반하는 하위그룹(SMI-LCT, SMI-LCI그룹)에서 호흡 기능의 약화나 호흡조절 능력이 더 저 하되어 있음을 시사한다. 호흡기능의 약화는 청지각적으로는 음성강도가 약화되는 양상으로 나타나지만 발화 과정에서 쉼 시간이 길거나 쉼의 빈도가 증가하는 것도 호흡기능의 제약을 반영하기 때문이다. 즉 발화를 위해서는 기류가 지속적으로 조 달이 되어야 하므로(Yoo \& Shin, 2020) 호흡이 불충분하다면 발 화 중간에 쉼이 나타나게 마련이다. 뇌성마비 유형별로 쉼의 횟 수나 쉼의 시간을 살펴본 연구에서도 유형에 상관없이 쉼 빈도 가 높고, 쉼 구간이 길다는 결과를 제시하면서 한 호기에 산출 할 수 있는 충분한 호흡량을 갖추지 못하기 때문이라고 설명하 고 있다(Nam \& Kwon, 2005; Nam \& Kwon, 2009).

이러한 호흡능력의 문제는 NSMI와 SMI 그룹 간에 MPT를 통 해 호흡능력을 평가한 선행연구에서도 SMI에서 더 낮은 MPT 를 나타낸다고 보고하고 있다(Jeong, 2019). 또한 일반아동과의 비교연구에서도 뇌성마비 아동의 호흡능력은 일반아동에 비해 약 $50 \%$ 정도 더 낮은 수행력을 보인다고 하였다(Kim \& Lee, 2018).

정상적인 호흡이 이루어지기 위해서는 신체조절 능력과 함 께 항중력적 움직임을 통한 근력의 발달, 팔다리 움직임 및 흥 곽의 발달이 요구된다(Lee, 2010). 그러나 뇌성마비 아동에서는 전신 근력의 약화와 경직, 비정상적인 운동기능이 동반되므로
이로 인해 흉곽이나 호흡근의 작용에도 제약이 있어 호흡문제 가 따르게 된다(Hardy, 1964).

경직형 뇌성마비아동은 특히 호기 비축량과 폐활량이 저하 되는 특성을 보이는데(Hardy, 1964) 이러한 호흡능력의 문제로 인해 발화 시에 쉄의 양상은 말문제를 동반하는 뇌성마비 그룹 에서 더 두드러지게 나타날 수 있는 것이다.

한편 뇌성마비의 발화에서 쉼의 특성을 청지각적으로 평가 하였을 때 짧은 구와 부적절한 쉼으로 평가하기도 한다(Nam et al., 2009). 이러한 특징을 보이는 이유로 불필요한 공기 소모가 많아 한 호흡당 산출할 수 있는 발화길이가 짧고, 잦은 쉼이 나 타나면서 부적절한 위치에서 쉼이 나타난 것으로 판단했기 때 문이다(Nam et al., 2009). Lee \& $\operatorname{Kim}(2017)$ 은 부적절한 쉼의 유 형에는 어절 내 쉼, 부절절한 길이의 쉼, 긴 들숨이 해당된다고 언급하였다. 본 연구에서 발화 동안에 나타난 부적절한 쉼의 형 태는 부적절한 길이의 쉼이 가장 두드러진 특징이었다. 특히 SMI 그룹에서는 어절 간에 나타나는 쉼이 횟수도 빈번하였고, 쉼 시간도 더 길게 나타났다.

그러나, 본 연구에서 살펴본 부적절한 쉼의 특성으로 어절 내 쉼이나 길고 크게 들리는 들숨의 형태는 관찰되지 않았다. 이러 한 이유로는 본 연구에는 경직형 뇌성마비 아동만 참여하였기 때문으로 사료된다. 불수의운동형과 경직형 뇌성마비 아동을 비교한 선행연구(Jeong \& Sim, 2020)에서는 모음연장발성 수행 과정에서 불수의운동형 뇌성마비 아동이 발성 시 갑자기 음성 이 끊기거나 들숨에서 발성을 하는 등의 불수의적인 특성을 보 인다고 언급하고 있는데, 이러한 유형별 호흡양상의 차이가 부 적절한 쉼의 특성에서도 영향을 끼친 것으로 보여 진다.

또한 파킨슨병으로 인한 과소운동형 마비말장애를 대상으로 한 연구(Hammen \& Yorkston, 1996)와도 쉼의 형태에서 차이를 보인다. 즉 PACER를 사용하지 않는 평상 시 발화에서는 구문 적으로 구나 절 사이에서 부적절한 쉼이 나타났는데, 본 연구에 서는 어절이 끝나는 구간 즉, 어절 간에 쉼이 나타났다는 점에 서 그 양상이 달랐다.

이러한 차이는 신경학적으로 볼 때 경직형 뇌성마비와 파킨 슨병의 병소 위치가 다르기 때문으로 볼 수 있다. 파킨슨병은 기저핵 조절회로의 손상으로 인한 추체외로계의 손상과 관련 이 있으나 본 연구에 참여한 경직형 뇌성마비 아동의 병변은 추 체로 손상과 관련이 있다. 따라서 신경학적 병변이 다르며 이에 따른 호흡 및 말장애 양상에서의 차이가 있기 때문에 쉼이 나타 나는 구간도 달랐을 것으로 보여 진다.

\section{3. 말속도, 쉼 및 말명료도와의 관계}

말속도와 말명료도, 조음속도와 말명료도 간에는 유의한 정 적인 상관을 보였다. 이 결과는 말속도나 조음속도가 빠른 경우 에 말명료도도 증가하였다는 것을 의미한다. 이는 조음속도 (Jeong et al., 2016; Peeters et al., 2009)나 말속도(Lee \& Kim, 2012)가 빠를수록 말명료도가 높다는 선행연구와 일치한다.

바꾸어 말하면 말속도가 느린 것이 말명료도 향상과 관련이 있다고 볼 수는 없다는 것이다. 이러한 결과를 뒷받침해 줄 수 
있는 근거들을 살펴보면 McAuliffe et al.(2017)은 느린 말속도 조건이 말명료도를 유의하게 높일 수 있는 전략이 아니라는 결 과를 제시하였다. Jeong et al.(2016)의 연구에서도 상대적으로 조음속도가 더 빨랐던 이완형 마비말장애 집단에서 말명료도 와 상관을 나타내었고, 이러한 결과를 통해 말명료도 향상을 위 해서는 말속도보다는 조음정확도를 더 고려할 필요가 있다고 제안하였다. Kim \& Ko(2009) 또한 느린 속도일 때의 오류율이 평상시 발화속도와 차이를 보이지 않는다고 하면서 느린 말속 도가 말명료도 향상에 언제나 도움이 되는 것은 아니라고 제안 하고 있다. 또 실제 말명료도 증진 전략이 적용 되려면 말명료 도가 $60 \%-90 \%$ 수준일 때는 효과가 있지만 $60 \%$ 이하이거나 $90 \%$ 이상인 경우에는 이러한 전략이 효과를 미치지 않는다고 설명하고 있다(Kim \& Ko, 2009).

느린 말속도가 말명료도 증진과 유의한 관련성이 없다는 입 장에서는 오히려 말속도보다는 조음체계(Lee et al., 2014)가 가 장 큰 역할을 하고, 자음정확도 향상(Lee \& Kim, 2012)이나 모 음 포먼트가 말명료도 증진에 더 성공적인 전략이라고 제안하 고 있다(McAuliffe et al., 2017). Lee et al.(2012) 역시 말명료도 매개변수 가운데에 자음정확도가 높은 상관을 보인다고 언급 한 바 있고, 말속도는 말명료도보다는 말의 자연스러움과 더 관 련이 있으며, Lee et al.(2007)도 말명료도가 낮은 화자는 오히려 발화속도가 더 느리다고 언급하기도 하였다.

기존의 연구들에서 말속도를 느리게 조절하는 것이 말명료 도 개선에 도움이 된다는 것은 결국 말속도를 조절하는 과정에 서 구강 움직임의 범위를 확대함으로써 모음 포먼트에 변화를 주게 되고, 정확한 조음점에 도달하지 못하는 현상(undershoot) 을 보완할 수 있기 때문에 말명료도가 향상되는 것이라고 판단 할 수 있다. 즉 발화 과정에서 구강운동 기능이 정확해지고, 협 응이 적절하게 이루어져 자음정확도가 향상되어야 말명료도는 향상된다고 볼 수 있다. 따라서 말명료도의 필요조건으로는 말 산출의 속도(speed)와 정확성(accuracy)이 모두 갖추어져야 할 것으로 생각된다.

본 연구에서는 쉄(쉄 시간 비율, 평균 쉼 횟수, 평균 쉼 시간) 과 말명료도와는 유의한 상관을 보이지 않았다. 이러한 결과가 나타난 이유로 쉼은 말명료도보다는 오히려 말의 유창성과 관 련이 있기 때문으로 사료된다. 또한 앞서 언급한 바와 같이 쉼 이 나타나는 구간이 어절 간에 나타났기 때문에 구문적으로 부 적절한 위치 즉 어절 내에 나타나는 경우에 비해서는 말명료도 에 적게 영향을 미쳤을 것으로 보인다. 아울러 본 연구의 실험 과제는 운반구 문장을 사용하여 말명료도를 측정하였으므로 쉄의 패턴이 비교적 일정한 상태에서 운반구에 포함된 단어에 더 집중하여 평정했을 수도 있기 때문에 쉼의 요소들이 말명료 도와 관련이 적은 것으로 나타났을 수도 있다. 따라서 후속연구 에서는 Hammen \& Yorkston(1996)이 제안한 바와 같이 쉄의 위 치를 변경시켰을 때 말명료도에 미치는 영향은 어떠한지 알아 볼 필요가 있다고 사료된다.

그러나 쉼의 횟수와 말명료도 간에 높은 상관을 보인다는 결 과도 있다(Lee et al., 2007). 이는 선행연구가 20-30대의 뇌성마
비 성인을 대상으로 4-6어절의 읽기과제를 통해 분석하였다면 본 연구에서는 4-13세의 경직형 뇌성마비 아동을 대상으로 3어 절 문장 따라말하기를 통해 분석하였다. 이렇듯 연구대상의 연 령이나 과제가 상이하므로 결과가 다르게 나올 수 있다고 추측 된다.

본 연구에서는 말문제가 있는 뇌성마비 아동(SMI-LCT, SMI-LCI 그룹)의 말속도와 조음속도는 말문제가 없는 아동(NSMI-LCT, NSMI-LCI 그룹)에 비해 느린 특성을 보이는 것을 확인하였고, 하위그룹별로 쉼의 특성까지 비교하여 제시한 점에서 의의가 있다. 또한 본 연구의 결과는 말속도와 조음속도가 경직형 뇌성 마비 아동의 말명료도에 중요한 역할을 한다는 시사점을 제공 한다.

연구의 제한점과 후속연구를 위한 제안은 다음과 같다. 본 연 구에서는 3 어절의 따라말하기 과제를 통해 말속도를 측정하였 으므로 다양한 문장 길이나 자연스러운 발화를 고려하지 못하 였다. 문장구조의 복잡성이나 인지적 부담에서의 차이가 조음 구간에 영향을 미친다고 언급하고 있으나(Yoo \& Shin, 2020) 본 연구에서는 운반구가 포함된 동일 어절의 문장을 과제로 하였 으므로 언어능력이 다른 하위그룹 간에 유의한 차이를 보이지 않은 것으로 사료된다. 후속연구에서는 문장 발화 길이나 발화 과제를 다양하게 하여 하위그룹 간 말속도와 쉼의 특성을 살펴 볼 필요가 있다. 둘째, 경직형 뇌성마비 아동만을 대상으로 하 여 뇌성마비 아동 전체의 특성이라고 일반화하기는 어렵다. 후 속연구에서 불수의운동형이나 실조형 등 다양한 유형을 대상 으로 한 연구가 진행된다면 더 많은 정보를 제공해 줄 수 있을 것으로 사료된다.

\section{References}

Allison, K. M., \& Hustad, K. C. (2018). Acoustic predictors of pediatric dysarthria in cerebral palsy. Journal of Speech, Language, and Hearing Research, 61(3), 462-478.

Darling-White, M., Sakash, A., \& Hustad, K. C. (2018). Characteristics of speech rate in children with cerebral palsy: A longitudinal study. Journal of Speech, Language, and Hearing Research, 61(10), 2502-2515.

Goldman-Eisler, F. (1968). Psycholinguistics: Experiments in spontaneous speech. London, UK: Academic Press.

Hammen, V. L., \& Yorkston, K. M. (1996). Speech and pause characteristics following speech rate reduction in hypokinetic dysarthria. Journal of Communication Disorders, 29(6), 429-445.

Han, J. H., Sung, J. E., Sim, H. S., \& Lee, Y. M. (2013). Effects of speaking rate manipulation and the severity of dysarthria on speech intelligibility and acoustic parameters in persons with cerebral palsy. Journal of Speech-Language \& Hearing Disorders, 22(1), 35-54.

Hardy, J. (1964). Lung function of athetoid and spastic quadriplegic children. Developmental Medicine and Child Neurology, 6(4), 
378-388.

Hodge, M. M., \& Gotzke, C. L. (2014). Construct-related validity of the TOCS measures: Comparison of intelligibility and speaking rate scores in children with and without speech disorders. Journal of Communication Disorders, 51, 51-63.

Hustad, K. C., Gorton, K., \& Lee, J. (2010). Classification of speech and language profiles in 4-year-old children with cerebral palsy: A prospective preliminary study. Journal of Speech, Language, and Hearing Research, 53(6),1496-1513.

Jeong, P. Y. (2019). Analysis of subgroup distribution and discriminant function in children with cerebral palsy based on Speech Language Profile Group (Doctor's thesis). Ewha Womans University, Korea.

Jeong, P. Y., \& Sim, H. S. (2020). A comparative study of the acoustic characteristics of the vowel /a/ between children with spastic and dyskinetic cerebral palsy. Phonetics and Speech Sciences, 12(1), 65-74.

Jeong, P. Y., Sim, H. S., Jeong, S. H., \& Yim, D. (2016). The relationship among articulation rate, intelligibility and working memory in children with spastic and flaccid dysarthria. Phonetics and Speech Sciences, 8(2), 41-48.

Kim, J. O., \& Lee, C. Y. (2018). Comparison of speech mechanism between children with and without cerebral palsy. Journal of Speech-Language \& Hearing Disorders, 27(2), 147-157.

Kim, M. J., Pae, S., \& Park, C. I. (2007). Assessment of phonology and Articulation for children (APAC). Incheon, Korea: Human Brain Research \& Consulting.

Kim, S. J., \& Ko, H. J. (2009). The effects of speaking mode on intelligibility of dysarthric speech. Phonetics and Speech Sciences, 1(4), 171-176.

Kim, Y. T., Hong, G. H., Kim, K. H., Jang, H. S., \& Lee, J. Y. (2010). Receptive \& Expressive Vocabulary Test (REVT). Seoul, Korea: Seoul Community Rehabilitation Center.

Lee, E. K., \& Kim, J. C. (2012). Correlation of speech rate changes on intelligibility and acceptability in dysarthric speakers. Journal of Speech-Language \& Hearing Disorders, 21(3), 127-144.

Lee, H. I., \& Kim, S. J. (2017). Comparison of overall speaking rate and pause between children with speech sound disorders and typically developing children. Phonetics and Speech Sciences, 9(2), 111-118.

Lee, H. Y. (2010). Effects of breathing exercise on pulmonary function and respiratory muscle strength in children with spastic cerebral palsy (Doctoral dissertation). Daegu University, Korea.

Lee, J., Hustad, K. C., \& Weismer, G. (2014). Predicting speech intelligibility with multiple speech subsystem approach in children with cerebral palsy. Journal of Speech, Language, and Hearing Research, 57(5), 1666-1678.

Lee, O. B., Park, S. H., \& Nam, H. W. (2012). Correlation between the parameters of speech intelligibility by speakers with cerebral palsy: A preliminary study. Journal of Speech-Language \& Hearing Disorders, 21(3), 115-126.

Lee, S. H., Ko, H. J., \& Kim, S. J. (2007). Prosodic properties in the speech of adults with cerebral palsy. Journal of Korean Speech Society: Speech, 64, 39-51.

McAuliffe, M. J., Fletcher, A. R., Kerr, S. E., O'Beirne, G. A., \& Anderson, T. (2017). Effects of dysarthria type, speaking condition, and listener age on speech intelligibility. American Journal of Speech-Language Pathology, 26(1), 113-123.

Nam, H. W., Ahn, J. B., \& Jung, H. (2009). The auditory-perceptual characteristics of articulation and prosody by the types of cerebral palsy in reading tasks. Journal of Speech-Language \& Hearing Disorders, 18(4), 91-103.

Nam, H. W., \& Kwon, D. H. (2005). Prosodic characteristics in person with spastic and athetoid cerebral palsy. Journal of Speech-Language \& Hearing Disorders, 14(2), 111-127.

Nam, H. W., \& Kwon, D. H. (2009). A comparative study of the characteristics of the subsystems for speech production by the types of the cerebral palsy. Journal of Speech-Language \& Hearing Disorders, 18(2), 17-50.

Nip, I. S. B. (2013). Kinematic characteristics of speaking rate in individuals with cerebral palsy: A preliminary study. Journal of Medical Speech-Language Pathology, 20(4), 88-94.

Nip, I. S. B., \& Green, J. R. (2013). Increases in cognitive and linguistic processing primarily account for increases in speaking rate with age. Child Development, 84(4), 1324-1337.

Palisano, R., Rosenbaum, P., Walter, S., Russell, D., Wood, E., \& Galuppi, B. (1997). Development and reliability of a system to classify gross motor function in children with cerebral palsy. Developmental Medicine and Child Neurology, 39(4), 214-223.

Peeters, M., Verhoeven, L., \& de Moor, J. (2009). Predictors of verbal working memory in children with cerebral palsy. Research in Developmental Disabilties, 30(6), 1502-1511.

Pennington, L., Miller, N., Robson, S., \& Steen, N. (2010). Intensive speech and language therapy for older children with cerebral palsy: A systems approach. Developmental Medicine \& Child Neurology, 52(4), 337-344.

Redfold, M. A. (2014). The perceived clarity of children's speech varies as a function of their default articulation rate. The Journal of the Acoustical Society of America, 135(5), 2952-2963.

Stathopoulos, E. T., Huber, J. E., Richardson, K., Kamphaus, J., DeCicco, D., Darling, M., Fulcher, K., ... Sussman, J. E. (2014). Increased vocal intensity due to the Lombard effect in speakers with Parkinson's disease: Simultaneous laryngeal and respiratory strategies. Journal of Communication Disorders, 48, 1-17.

Yoo, D., \& Shin, J. (2020). Study on the realization of pause groups and breath groups. Phonetics and Speech Sciences, 12(1), 19-31. 
- 정필연 (Pil Yeon Jeong)

이화여자대학교 아동발달센터 연구원

서울특별시 서대문구 성산로 533

Tel: 02-3277-3268

Email:.jpy@ewha.ac.kr

관심분야: 뇌성마비, 말명료도, 말운동장애

- 심현섭 (Hyun Sub Sim) 교신저자

이화여자대학교 대학원 언어병리학과 교수

서울특별시 서대문구 이화여대길 52

Tel: 02-3277-3538

Email:simhs@ewha.ac.kr

관심분야: 유창성장애, 음성장애, 말명료도 


\title{
경직형 뇌성마비 아동의 하위그룹별 말속도와 섬의 특성 및 말명료도와의 관계
}

\author{
정 필 연 $·$ 심 현 섭 ${ }^{2}$ \\ ${ }^{1}$ 이화여자대학교 아동발달센터, ${ }^{2}$ 이화여자대학교 언어병리학과
}

\begin{abstract}
국문초록
본 연구의 목적은 경직형 뇌성마비 아동의 하위그룹별로 말속도와 쉼에서 차이가 있는지 살펴보고, 말명료도와의 관련성에 대해서 알아보고자 하였다. 연구대상은 경직형 뇌성마비 아동 26 명이 참여하였다. 말문제와 언어문제가 없는 NSMI-LCT 4명, 말문제는 없지만 언어문제가 있는 NSMI-LCI 그룹 6 명, 말문제가 있지만 언어문제는 없는 SMI-LCT 6명, 말과 언어문제를 모두 동반하는 SMI-LCI 그룹 10 명이 참여하였다. 연구과제는 문장 따라말하기였 고, Praat을 통해 말속도, 조음속도, 쉼 시간의 비율, 평균 쉼 횟수, 평균 쉼 시간을 측정하였다. 연구결과, 첫째, 말속 도와 조음속도는 언어문제의 유무와 관계없이 NSMI와 SMI 그룹 간에 유의한 차이가 나타났다. 둘째, NSMI에 비 해 SMI 그룹에서에서 쉼 시간의 비율은 더 높고, 쉼 횟수는 더 빈번하였으며 쉄 시간은 더 길게 나타났다. 셋째, 말 속도와 조음속도는 말명료도와 유의한 상관을 나타내었다. 본 연구의 결과는 느린 말속도가 SMI 그룹의 말산출 과 정에서 나타나는 주요한 특성이고, 말명료도에 있어서 조음속도와 말속도가 중요한 역할을 함을 시사한다.
\end{abstract}

핵심어: 경직형 뇌성마비, 말속도, 쉼, 말명료도

\section{참고문헌}

김민정, 배소영, 박창일 (2007). 아동용 발음평가 $A P A C)$. 인천: 휴 브알앤씨.

김수진, 고현주 (2009). 뇌성마비 성인의 발화유형에 따른 명료

도. 말소리와 음성과학, 1(4), 171-176.

김영태, 홍경훈, 김경희, 장혜성, 이주연 (2010). 수용·표현어휘 력 검사 $(R E V T)$. 서울: 서울장애인종합복지관.

김재옥, 이조영 (2018). 뇌성마비 아동과 일반 아동의 말산출 하

부 체계 구조 및 기능 비교. 언어치료연구, 27(2), 147-157.

남현욱, 권도하 (2005). 경직형 및 불수의 운동형 뇌성마비인의 운율 특성. 언어치료연구, 14(2), 111-127.

남현욱, 권도하 (2009). 뇌성마비 유형별 구어산출 하위체계 특성 비교. 언어치료연구, 18(2), 17-50.

남현욱, 안종복, 정훈 (2009). 읽기과제에서의 뇌성마비 유형별 조음 및 운율의 청지각적 특성. 언어치료연구, 18(4), 91-103.

유도영, 신지영 (2020). 휴지 단위와 호흡 단위의 실현 양상 연구.

말소리와 음성과학, 12(1), 19-31.

이숙향, 고현주, 김수진 (2007). 뇌성마비 성인의 발화의 운율특 성, 말소리, 64, 39-51.

이옥분, 박상희, 남현욱(2012). 뇌성마비 화자의 말명료도 매개변 수 간의 상관성 연구: 예비연구. 언어치료연구, 21(3), 115-126. 이은경, 김지채 (2012). 마비말장애 화자의 말속도에 따른 말 명
료도 및 말 용인도. 언어치료연구, 21(3), 127-144.

이혜영 (2010). 호흡훈련이 경직성 뇌성마비아의 폐기능 및 호흡 근력에 미치는 영향, 대구대학교 박사학위논문.

이흥임, 김수진 (2017). 말소리장애 아동과 일반 아동의 발화속도 와 쉼 비교. 말소리와 음성과학, 9(2), 111-118.

정필연 (2019). Speech Language Profile Group(SLPG) 분류체계에 근거한 뇌성마비 아동의 하위그룹 분포 및 판별요인분석. 이 화여자대학교 박사학위논문.

정필연, 심현섭 (2020). 경직형과 불수의운동형 뇌성마비아동의/ 아/ 모음 음향학적 비교. 말소리와 음성과학, 12(1), 65-74.

정필연, 심현섭, 정숙회, 임동선 (2016). 경직형과 이완형 마비말 장애아동에서 조음속도와 말명료도 및 작업기억능력 간의 관 계. 말소리와 음성과학, 8(2), 41-48.

한지후, 성지은, 심현섭, 이영미 (2013). 말속도 조절 및 중증도가 마비말장애 화자의 말명료도와 음향학적 파라미터에 미치는 영향. 언어치료연구, 22(1), 35-54. 